POLSKA AKADEMIA UMIEJĘTNOŚCI

Tom XIV

PRACE KOMISJI HISTORII NAUKI PAU

2015

Wojciech KOCUREK

Sika Group, Düdingen niedaleko Fryburga, Szwajcaria

wojtek.kocurek@op.pl

\title{
POLSKIE POCZĄTKI \\ WYDZIAŁU NAUK MATEMATYCZNYCH I PRZYRODNICZYCH \\ UNIWERSYTETU WE FRYBURGU \\ I POLSKI WKEAD \\ WE FRYBURSKĄ REWOLUCJĘ PRZEMYSLOWA
}

\begin{abstract}
Streszczenie
Artykuł został poświęcony spółkom wysokich technologii, założonym przez Polaków pod koniec XIX wieku w rolniczym kantonie Fryburg w Szwajcarii. W tekście wyróżnić można dwie części. W pierwszej autor stara się przedstawić rzeczywistość gospodarczą, społeczną i polityczną Fryburga w okresie intensywnej industrializacji na świecie i powstawania liberalnego systemu wolnego rynku. Nowe, katolicko-konserwatywne władze kantonu w tej szybko zmieniającej się rzeczywistości starały się doprowadzić do stworzenia całościowego, ale i odmiennego ustroju „republiki chrześcijańskiej”, którego celem miało być osiągnięcie sprawiedliwości społecznej, zgodnej ze wskazaniami Ewangelii.

By projekt ten doprowadzić do końca, rząd kantonalny nie uchylał się przed wykorzystaniem różnorodnych możliwości i środków, które pomogłyby osiągnąć ten cel. Decydenci z Georges'em Pythonem na czele potrzebowali wsparcia ze strony społeczeństwa świadomego zachodzących przemian. W związku z tym, niezbędnym stało się powołanie uczelni wyższej, zdolnej do kształtowania nowych postaw i poglądów mieszkańców regionu. Koszt jej powstania przekraczał jednakże wielokrotnie finansowe możliwości rolniczego i stosunkowo ubogiego kantonu fryburskiego. W tych mało sprzyjających okolicznościach sposobem na wyjście $\mathrm{z}$ impasu okazała się świadoma polityka industrializacji. Nowo tworzone instytucje przemysłowe miały przyczynić się do zwiększenia wpływów do kantonalnej kasy i poprzez to pozwolić na finansowanie uniwersytetu, który jednocześnie stawał się intelektualnym zapleczem dla formujących się instytucji przemysłowych.

W tę filozofię znakomicie wpisała się działalność polskich naukowców, która jest przedmiotem drugiej części artykułu. Polacy zaproszeni przez Pythona do współpracy: Józef Wierusz-Kowalski, Ignacy Mościcki i Jan Modzelewski - stworzyli podstawy Wydziału Nauk Matematycznych i Przyrodniczych Uniwersytetu we Fryburgu. Prowadzili w nim (oprócz działalności dydaktycznej) badania dotyczące między innymi syntezy kwasu azotowego i budowy kondensatorów elektrycznych. Przekonani o potrzebie wdrożenia do
\end{abstract}


szerokiej produkcji stworzonych przez siebie innowacji, sfinansowali i zbudowali pierwsze fabryki doświadczalne, a z czasem doprowadzili do powstania przemysłowych fabryk kwasu azotowego oraz kondensatorów wysokiego napięcia. Choć po zakończeniu pierwszej wojny światowej to zaangażowanie Polaków ustało, okres 30 lat badań i doświadczeń akademickich jasno pokazuje, że świadome współdziałanie decydentów politycznych i wysoko kwalifikowanej kadry naukowej może przynieść zaskakujące i nieoczekiwane efekty.

Słowa kluczowe: Uniwersytet we Fryburgu, Wydział Nauk Matematycznych i Przyrodniczych, industrializacja, nauki stosowane, przemysł, kwas azotowy, kondensatory, wyładowania elektryczne, saletra, synteza azotu z tlenem, „republika chrześcijańska”, katolicka nauka społeczna, spółka akcyjna, fabryka, patenty, Towarzystwo Kwasu Azotowego, Szwajcarska Fabryka Kondensatorów, Towarzystwo Generalne Kondensatorów Elektrycznych

\section{Wprowadzenie}

XIX-wieczna rewolucja przemysłowa miała zasięg światowy, jednak nie wszędzie przebiegała równie intensywnie i skutecznie. Środowisko polityczne, stosunki religijne, stopień rozwoju społeczeństwa, najbliżsi sąsiedzi, jak i dalecy sprzymierzeńcy - wszystko to mogło mieć, i miało, przemożny wpływ na rezultaty rewolucji przemysłowej. Dlatego też trudno jednoznacznie określić warunki gwarantujące jej powodzenie lub takie, które skazywałyby ją na pewną porażkę. Nie jest regułą, że jedynie rządy liberalne i postępowe otwierały społecznościom możliwość pro-industrialnego działania. Chęć modernizacji wynikała $z$ różnych powodów.

Fryburg to przykład kantonu (a więc de facto państwa) raczej niepredestynowanego do wejścia na drogę industrializacji. W porównaniu z innymi krajami związkowymi Konfederacji Szwajcarskiej raczej ubogi, pod rządami ugrupowań o charakterze katolicko-konserwatywnym - potrafił stworzyć spójną wizję państwa i społeczeństwa szczęśliwego. Realizował ją w sposób konsekwentny, a czasem i sprytny, metodami stosowanymi w społeczeństwach najbardziej rozwiniętych. Mało zważając na stan finansów państwa, do zrealizowania wytyczonych celów nie obawiał się zaangażować i cudzoziemców, o ile podążali oni wspólnie tak wytyczoną drogą. By dobrze zrozumieć istotę, a przede wszystkim skalę przemian we Fryburgu, konieczne jest przyjrzenie się pokrótce temu systemowi i zasadom jego funkcjonowania, a także charakterowi społeczeństwa i gospodarki kantonu fryburskiego.

\section{Jak skutecznie uprzemysłowić ubogi region rolniczy?}

Kanton fryburski nie należał do prekursorów rewolucji przemysłowej w Szwajcarii. W połowie lat 80. XIX wieku, po kilku dekadach rządów radykałów i zastępujących ich kilkakrotnie konserwatystów, władzę w kantonie przejęła partia konserwatywno-katolicka. Nowi politycy z Georgesem Pythonem na czele otrzymali po poprzednikach kraj, 
w którym procesy modernizacyjne co prawda postępowały, ale w sposób raczej chaotyczny, więc ich rezultaty były mierne. Dla wielu historyków szwajcarskich papierkiem lakmusowym jest sprawa kolei. ${ }^{1}$ Choć cała Szwajcaria miała znaczne zapóźnienia w tym zakresie (już w 1851 roku państwa niemieckie dysponowały siecią o długości 6 tys. km, a Szwajcaria pierwsze $20 \mathrm{~km}$ zbudowała dopiero w 1847 roku), to kanton fryburski mógł „poszczycić się” jednym z ostatnich miejsc we wprowadzaniu kolei żelaznej. Problemem była nie tylko budowa samej linii kolejowej, ale także jej przebieg. Ten bowiem, który bardziej sprzyjał rozwojowi całej Konfederacji Szwajcarskiej, nie był korzystny dla samego kantonu. Ostatecznie sieć kolejowa została zbudowana przez liczne kompanie prywatne. Efekty były mniej niż zadowalające, przede wszystkim z powodu wysokich nakładów, a co gorsza, zyski ekonomiczne nowo powstałej kolei okazały się mniejsze niż się powszechnie spodziewano.

Postępy liberalizmu w latach 60. przyczyniły się także do zwycięstwa idei otwartych granic między państwami europejskimi. Szwajcaria również znalazła się w tym nurcie, podpisując traktaty o wolnym handlu z Francją, Włochami, a także z Niemieckim Związkiem Celnym. Taka polityka gospodarcza zamiast przyczynić się do rozwoju ekonomicznego Fryburga i kantonu, powodowała raczej straty. $\mathrm{Z}$ wielkim trudem wybudowana sieć kolejowa umożliwiła napływ tańszego zboża z innych regionów, zwłaszcza z Europy Wschodniej. Nadchodzący kryzys ekonomiczny zmusił wiele krajów do wprowadzenia ceł zaporowych, więc eksport szwajcarskich produktów rolnych przestał się opłacać. Polityka leseferyzmu zamiast pełnić rolę katalizatora przedsiębiorczości - przyczyniła się do pogłębienia zapaści gospodarczej. Nieodpowiednie decyzje polityczne liberałów fryburskich spowodowały nasilenie się ruchów syndykalistycznych. Zaczęły powstawać towarzystwa rolnicze, których celem była obrona wytwórców żywności przed konkurencją, ale także przed szeroko rozbudowanym systemem pośrednictwa w sprzedaży produktów rolnych. Zdarzały się także manifestacje i strajki rolnicze.

Pomimo sytuacji kryzysowej rola i znaczenie gospodarki rolnej w kantonie fryburskim pozostawały przemożne. W tym niewielkim, ale samowystarczalnym ekonomicznie kantonie utrzymywano równowagę pomiędzy uprawą zbóż i ziemią przeznaczoną na pastwiska. Dzięki temu w latach 70. produkcja mleka i jego przetworów wzrosła dwukrotnie w stosunku do lat 50. We wspomnianym okresie dał się także zaobserwować wzrost ceny sera z 50 do 80 centymów za kilogram. Ten profil gospodarki nie pozwalał jednak na stworzenie najmniejszych podstaw dla działalności przemysłowej. O ile w całej Szwajcarii pomiędzy 1850 a 1880 rokiem procent populacji wielkoprzemysłowej zwiększył się z 3,09\% do $11,3 \%$, to w kantonie fryburskim podobnej tendencji wzrostowej próżno się doszukiwać. ${ }^{2}$ Wytwórczość prowadzona na większą skalę była ściśle zawiązana jedynie z gospodarstwami rolnymi. Na przykład wyplatanie słomy miało w gruncie rzeczy wszelkie znamiona średniowiecznej pracy nakładczej. Odbywało się ono w gospodarstwach wiejskich, będących grupą podwykonawców dla fabryk położonych w innych częściach

\footnotetext{
1 Walter 1981, ss. 897-898.

2 Ibidem, s. 902.
} 
kraju. Innym rodzajem przemysłu surowcowego były tartaki, zajmujące się jedynie wycinką drzew, które spławiane na południe Francji stanowiły surowiec do budowy statków, a także wykorzystywano je jako materiał opałowy. Ponieważ popyt na drewno był bardzo wysoki, przyczyniał się on do znacznej dewastacji fryburskich lasów.

Do realizacji pierwszego przedsięwzięcia przemysłowego większej wagi doszło we Fryburgu w 1870 roku, a była to zapora wodna projektu inżyniera Guillaume’a Rittera. Miała ona nie tylko zaopatrywać mieszkańców w bieżąca wodę, ale także, dzięki systemowi kabli mechanicznych, dostarczać energię mechaniczną planowanym w okolicy fabrykom. $\mathrm{Z}$ wielkim rozmachem powstała zapora, a także jeden z pierwszych zakładów przemysłowych - fabryka wagonów. Kryzys ekonomiczny, który wybuchł w latach 70. XIX wieku, walnie przyczynił się jednak do upadku pomysłu stworzenia z Fryburga ważnego centrum przemysłowego. ${ }^{3}$

W warunkach takich przeobrażeń, a niekiedy także i mało zorganizowanych działań, zaczyna dochodzić do przewartościowań w pojmowaniu roli państwa i jego organów wykonawczych. We Fryburgu jednym z myślicieli, który z czasem stał się także inspiratorem nowej partii konserwatywno-katolickiej, był kanonik Joseph Schorderet. Od połowy lat 60. XIX wieku - w opozycji do ówcześnie urzędującej władzy - zaczął on tworzyć całościowy system filozoficzny, który zwykł nazywać królestwem społecznym Jezusa Chrystusa. Warto przywołać jego słowa, które często powtarzał na łamach założonej przez siebie gazety La Liberté:

Budujemy demokrację katolicką, do której należy przyszłość. Stwórzmy z Fryburga rodzaj miasta mistycznego, demokracji teokratycznej, gdzie teorie socjalne i polityczne Kościoła byłyby wprowadzane w życie (Philipona 1924/1925).

Te i podobne pomysły Schordereta mogłyby na zawsze pozostać jego pobożnym życzeniem, gdyby nie fakt, że popierał je młody polityk Georges Python o dalekosiężnych ambicjach. W 1881 roku, jako dwudziestopięciolatek, uzyskał mandat deputowanego do parlamentu kantonalnego. W 1885 roku wspólnie z Schorderetem utworzył nową partię konserwatywno-katolicką, a rok później - został członkiem rządu kantonalnego odpowiedzialnym za edukację i kulturę. ${ }^{4}$ Python, który z czasem stał się rządowym liderem, starał się stworzyć egzekutywę radykalną i postępową w działaniu, ale katolicką w swojej doktrynie. Zdecydowanie próbował ominąć niebezpieczeństwa liberalizmu, socjalizmu, ale także i liberalizmu chrześcijańskiego, zwalczanego przez Piusa IX.

Python spodziewał się, że taką postawą zaskarbi sobie szerokie poparcie ze strony hierarchii Kościoła katolickiego, dominującego w kantonie. Jego rola i pozycja społeczna była na owe czasy nie do pominięcia. Wystarczy wspomnieć, że w 1885 roku zorganizowano we Fryburgu Międzynarodowy Kongres Eucharystyczny, a prace kardynała Gasparda Mermilloda, biskupa Lozanny i Genewy, i powołanej przez niego Unii Fryburskiej, w za-

\footnotetext{
3 Walter 1973/1974, ss. 117-124.

${ }^{4}$ Bugnard 1981, s. 875.
} 
kresie katolickiej nauki społecznej nie były bez znaczenia dla papieskiej encykliki Rerum novarum. ${ }^{5}$

Python, Schorderet i ich stronnicy byli świadomi, że w społeczeństwie rolniczym, w którym dominowała mała i średnia własność, kompleksowa wizja republiki chrześcijańskiej może zostać odrzucona jako zbyt złożona i skomplikowana. Wykraczała ona bowiem daleko poza oczekiwania ich wyborców i sympatyków, zainteresowanych przede wszystkim poprawą własnego statusu materialnego. Zaistniała zatem potrzeba stworzenia szerokiej bazy mogącej wspomóc, a z czasem i twórczo rozwijać idee chrześcijańskiej republiki. Według Pythona najlepszym sposobem realizacji tego planu było utworzenie uniwersytetu, który miał stanowić zwornik całego systemu. W zamyśle szefa rządu jego zadania miały być wielorakie. Przede wszystkim, dzięki autorytetowi, jakim powinien się cieszyć, uniwersytet miał wspomagać budowę republiki chrześcijańskiej, a chroniąc młodzież przed zgubnymi zakusami nowoczesności, miał doprowadzić do stworzenia warstwy kadr, intelektualistów, urzędników i zwolenników nowej republiki.

\section{Nowy uniwersytet \\ i jego Wydział Nauk Matematycznych i Przyrodniczych}

Założenie nowego uniwersytetu nie było ani rzeczą łatwą do przeprowadzenia, ani tanią. Uczelnia w ubogim kantonie byłaby sporym obciążeniem dla jego budżetu. Sprzeciw wyrażał także episkopat szwajcarski, nieprzychylny powstaniu katolickiego uniwersytetu niezależnego od Kościoła instytucjonalnego i podległego wyłącznie władzom kantonalnym. Niezrażony przeciwnościami Python podążał wyznaczoną ścieżką. Jego wysłannik, Caspar Decurtins, rozpoczął negocjacje z papieżem w sprawie uzyskania zgody na utworzenie wydziału teologicznego. Podczas licznych wojaży po Europie poszukiwał on także wykładowców dla nowego uniwersytetu. Był w Niemczech, Francji, Belgii i Austrii. Dotarł również i do Krakowa, gdzie rozmawiał z rektorem Stanisławem Tarnowskim. ${ }^{6}$

Ostatecznie uniwersytet powstał w 1889 roku. W celu zapewnienia stałego dopływu środków finansowych umożliwiających jego funkcjonowanie Python przeforsował szereg decyzji, które z czasem przyniosły niewątpliwe efekty. Przede wszystkim w 1888 roku znacjonalizował wspomnianą wcześniej zaporę wodną. Dokończył jej budowę i stworzył spółkę zarządzająca dystrybucją prądu elektrycznego i wody w kantonie. Przedsiębiorstwo to zaczęło wkrótce spełniać swoje zadania, stając się źródłem sporych dochodów dla kantonalnej kasy. W 1892 roku powołano Kantonalny Bank Fryburski, którego zyski w przeważającej części były przeznaczone na funkcjonowanie nowo powstałej uczelni. ${ }^{7}$

Pierwszy rok akademicki (1889) zainaugurowano jeszcze bardzo skromnie, bowiem zajęcia rozpoczęły się jedynie na wydziale prawa i wydziale filozoficznym. Python nie ustawał jednak w zamierzeniach. Zgodnie z ustawą parlamentu kantonalnego, podjętą w 1886

\footnotetext{
${ }^{5}$ Ibidem, s. 879.

6 Altermatt 1991, ss. 61-64.

7 Jordan 1943, ss. 18-20.
} 
roku, projekt uniwersytetu zakładał (oprócz dwóch wcześniej wspomnianych) utworzenie wydziałów teologicznego, matematycznego oraz podstaw wydziału medycznego. ${ }^{8}$ Szczególnym zainteresowaniem szefa rządu cieszyła się ta część przedsięwzięcia, która zakładała otwarcie wydziału matematycznego. Upatrywał on w nim szansę na wyjście z impasu i zmodernizowanie ubogiego i ciągle jeszcze rolniczego kantonu fryburskiego.

Decyzję o utworzeniu Wydziału Matematyczno-Przyrodniczego parlament kantonalny podjął dopiero podczas majowej sesji w 1895 roku. Środki na jego utrzymanie zapewniały dochody z wodociągów i elektrowni. Miejsce na przyszłą siedzibę także nie zostało wybrane przypadkiem. Przeznaczono na nią pomieszczenia wspomnianej, a w tym czasie już zamkniętej, fabryki wagonów. Nieużyteczne hale produkcyjne, zbudowane w przemysłowej dzielnicy Fryburga zostały zamienione w sale wykładowe i laboratoria. ${ }^{9}$

Pierwszym profesorem nowego wydziału został Józef Wierusz-Kowalski, który od 1892 roku piastował stanowisko docenta w nieodległym Bernie. Pomimo młodego wieku - miał on wówczas niespełna 30 lat - mógł pochwalić się już licznymi projektami badawczymi na wielu uniwersytetach europejskich. Po studiach w Warszawie i Getyndze, Wierusz-Kowalski pracował w Berlinie, Würzburgu, a następnie w Zurychu, Bernie i Paryżu, współpracując z wielkimi sławami ówczesnej nauki: Wilhelmem Roentgenem, Woldemarem Voigtem, Augustem Kundtem czy małżeństwem Curie. ${ }^{10}$

Pomimo iż nowy wydział rozpoczął działalność w 1896 roku, Wierusz-Kowalski został zaangażowany już w 1894 roku. Prowadząc na Wydziale Filozoficznym wykłady o świetle, o energii i jej przekształceniach, a także o hipotezach kosmogonicznych, mógł on swobodnie zajmować się organizacją powierzonego mu Wydziału Matematyczno-Przyrodniczego. A dzieło to było ogromne, gdyż miał on za zadanie skonstruować całą jego strukturę i program studiów oraz przygotować procedury związane z organizacją studiów doktoranckich. Został także pierwszym dziekanem wydziału w latach 1896-1897 (funkcję tę piastował jeszcze w latach 1906-1907). Profesor Wierusz-Kowalski pozostał także dyrektorem Instytutu Fizyki przez cały okres pobytu we Fryburgu, aż do powrotu do Polski w 1919 roku. ${ }^{11}$

Rozległe kontakty naukowe Józefa Wierusza-Kowalskiego były z pewnością wynikiem jego szeroko zakrojonej pracy badawczej. Swoje studia poświęcił on zmianom właściwości mieszanin cieczy pod wpływem wysokiego ciśnienia oraz ich właściwościom optycznym. Studiował także luminescencję mieszanin ziem rzadkich ze związkami metali alkalicznych. Jeszcze inne z jego zainteresowań dotyczyły fosforescencji związków ziem rzadkich i związków organicznych. Badał on także zależności między widmami pochłaniania a widmami fosforescencji w niskich temperaturach. Te ostatnie prace zostały w 1912 roku uwieńczone nagrodą Uniwersytetu Harwardzkiego. ${ }^{12}$

\footnotetext{
8 Giovannini 1991, s. 777.

9 Ibidem, s. 783.

10 Średniawa, Zabiełło 1968-1969, ss. 558-560.

11 Ruffieux (red.) 1993, s. 963.

12 Średniawa, Zabiełło 1968-1969, s. 559.
} 
We Fryburgu Józef Wierusz-Kowalski kierował zespołem jedenastu profesorów, którzy współpracowali z nim w pierwszych latach istnienia instytutu. Wszyscy oni, na sposób niemiecki, przesuwali punkt ciężkości z badań podstawowych na nauki stosowane.

Sam Wierusz-Kowalski wyrażał przekonanie, że fizyk powinien kierować się w stronę potrzeb i oczekiwań instytucji przemysłowych. Te idee doskonale odpowiadały wizji państwa i społeczeństwa tworzonej we Fryburgu przez Pythona. Według niej uniwersytet miał przecież spełniać funkcję utylitarną, stając się kuźnią kadr bądź to dla administracji kantonu, bądź dla powstających fabryk i manufaktur. Z pewnością ta zgodność w sposobie postrzegania roli nauki i naukowca spowodowała, że Wierusz-Kowalski został tak serdecznie przyjęty w nowej placówce. Nie należy przecież zapominać o wysokich kosztach, które generują badania w dziedzinie nauk ścisłych. W tych dyscyplinach każdy z instytutów wymaga specyficznej infrastruktury. To samo tyczy się bibliotek i aparatury. Przewidywane subwencje instytucji przemysłowych miały te koszty w znaczny sposób pomniejszyć.

Dziedziną badawczą, w której najlepiej udało się Wieruszowi-Kowalskiemu połączyć tak przez niego wychwalane związki nauki i przemysłu, była synteza kwasu azotowego poprzez reakcję tlenu i azotu w łuku elektrycznym. Rozpoczęte w tym zakresie badania nabrały tempa wraz z przybyciem do Fryburga Ignacego Mościckiego - drugiego z polskich naukowców i wynalazców. Po kilkuletnim pobycie w Anglii, gdzie raczej nie miał on okazji, by wykorzystać i pogłębić swoje naukowe umiejętności, uzyskał stanowisko asystenta w instytucie kierowanym przez Wierusza-Kowalskiego. Mościcki po studiach chemicznych w Rydze został asystentem w Instytucie Fizyki, gdzie stworzył kondensatory działające bez uszkodzenia przy napięciu kilkudziesięciu tysięcy woltów, niezbędne do produkcji kwasu azotowego nową metodą. Ten ciąg pozornie niezwiązanych ze sobą zdarzeń wpisywał się w logikę zgodną z upowszechnianą przez Wierusza-Kowalskiego wizją badań, ściśle sprzężonych z sytuacją ekonomiczną tak na świecie, jak i w kantonie fryburskim.

Pod koniec XIX wieku dla wszystkich zainteresowanych było już jasne, że złoża chilijskiej saletry nie są wystarczające na potrzeby ciągle intensyfikującej się produkcji rolniczej. Tymczasem azot - niezbędny do produkcji saletry - stanowi, jak wiadomo, podstawowy składnik powietrza. Jego ilość jest więc na dobrą sprawę nieskończona, a cena praktycznie żadna. Uzyskanie azotu z powietrza, by następnie wykorzystać go do produkcji kwasu azotowego rozbijało się jednakże o przeszkody natury technicznej. Podstawowym problemem było doprowadzenie do syntezy azotu z tlenem, gdyż tlenek azotu był niezbędnym składnikiem do produkcji kwasu azotowego. Pomysłów na rozwiązanie tej kwestii było wiele. Próbowano metody spalania powietrza w specjalnych piecach, by uzyskać w ten sposób tlenek azotu, po czym przez jego absorbcję zamienić go na kwas azotowy. Pionierami w tej dziedzinie byli Amerykanie, jednakże zastosowane przez nich metody były kosztowne, a jednocześnie mało rentowne.

Mościcki elektrotechniką interesował się od początku pobytu we Fryburgu, a dodatkowo miał już doświadczenia w dziedzinie produkcji nitrozwiązków, wyniesione ze studiów w Rydze i w Warszawie. Rozpoczął więc badania nad uzyskaniem kwasu azotowego nie 
tylko na skalę laboratoryjną, ale przede wszystkim przemysłową. ${ }^{13}$ Posiłkując się badaniami angielskiego uczonego Williama Crookesa, który wyprodukował dwutlenek azotu przy pomocy łuku elektrycznego, a kwas azotowy poprzez syntezę z wodą, Mościcki opracował własna metodę. Sukces nie przyszedł jednak za pierwszym razem.

Jak sam opisuje to w autobiografii, do utleniania azotu atmosferycznego potrzebował bardzo wysokiego napięcia, aż do 50 tysięcy woltów i konieczne było zastosowanie odpowiednich do takiego napięcia kondensatorów. Chciał on bowiem uzyskać zmianę zwykłej częstotliwości prądu zmiennego na prąd oscylacyjny o okresie 10 tysięcy na sekundę, bo większa częstotliwość powodowała wzrost wydajności produktu na jednostkę energii elektrycznej. ${ }^{14}$

Tutaj jednak pojawiły się pierwsze trudności natury technicznej. Kondensatory niezbędne Mościckiemu do przeprowadzenia doświadczeń wówczas nie istniały. Nie produkowała ich ani fabryka aparatów elektrycznych w Cortaillaud, ani jedyny szwajcarski dostawca kondensatorów wysokiego napięcia - fabryka w kantonie Tessin. Tego typu urządzeń nie wytwarzała także znana włoska firma Tedeschi z Turynu. Nikt nie był w stanie sprostać potrzebom polskiego naukowca. Mościcki posiadał jednak szalenie przydatną umiejętność wykorzystywania i twórczego przekształcania doświadczeń i badań z różnorodnych, często pozornie ze sobą niepowiązanych gałęzi nauki. W zaistniałej sytuacji sam więc przystąpił do studiowania natury i zastosowania dielektryków. Wielką pomocą w tym zakresie okazały się dla niego badania Wierusza-Kowalskiego dotyczące szkła. To szkło właśnie posłużyło Mościckiemu do odegrania roli dielektryku w nowo konstruowanych kondensatorach. ${ }^{15}$

O wadze i skali badań nad kondensatorami niezbędnymi do uzyskania azotu z powietrza metodą Mościckiego świadczy również spora liczba prac doktorskich, powstałych w oparciu o przeprowadzane z ich użyciem doświadczenia. Konrad Kasperowicz opublikował pracę dotyczącą dielektryków ${ }^{16}$, Roman Wybranowski przeanalizował problem ładunku elektrycznego zgromadzonego na okładkach kondensatora ${ }^{17}$, Bruno Zdanowski opisał metodę pomiarów płynnej oporności ${ }^{18}$, a Jan Modzelewski stworzył studium o kondensatorach elektrolitycznych zbudowanych z elektrod aluminiowych. ${ }^{19}$

Pomimo trudności prace nad uzyskaniem azotu z powietrza postępowały, a liczne uzyskane już wówczas patenty pozwoliły Mościckiemu na rezygnację ze stanowiska asystenta i poświęcenie się jedynie pracy naukowej. Georges Python świadomy wagi tych eksperymentów umożliwił Ignacemu Mościckiemu korzystanie z pomieszczeń laboratoryjnych uniwersytetu, pomimo iż formalnie nie był on już jego pracownikiem.

\footnotetext{
13 Lichocka 2011, s. 73.

14 Mościcki 1993, s. 83.

15 Lichocka 2011, s. 77.

16 Kasperowicz 1904.

17 Wybranowski 1904.

18 Zdanowski 1904.

19 Modzelewski 1908.
} 
W październiku 1901 roku, po pierwszej w pełni udanej serii prób nad nową metodą uzyskiwania azotu z powietrza, profesor Wierusz-Kowalski i Mościcki zdecydowali o utworzeniu towarzystwa - jednostki innowacyjnej, która miała zapoczątkować produkcję kwasu azotowego. ${ }^{20}$ Do rozpoczęcia tego przedsięwzięcia konieczne były jednak spore nakłady finansowe, a żaden z nich nie posiadał wystarczających środków. Szczęśliwie dla obu naukowców w 1900 roku studia we Fryburgu rozpoczął Jan Modzelewski, pochodzący z ziemiańskiej rodziny z Podola. Jego ojciec posiadał dobra wielkości 1000 hektarów, którymi sprawnie zarządzał. Zajmował się on między innymi handlem zbożem spławianym do portu czarnomorskiego w Odessie. Młody Modzelewski zakończył właśnie studia w belgijskim Liège ze stopniem kandydata nauk przyrodniczych i we Fryburgu pod okiem Wierusza-Kowalskiego rozpoczął prace nad rozprawą doktorską. Prawie równocześnie (1901) objął też stanowisko asystenta profesora po rezygnacji Mościckiego, zajętego próbami utleniania azotu. Skuteczność Wierusza-Kowalskiego w załatwianiu spraw związanych z asystenturą Mościckiego, a później Modzelewskiego świadczy bezsprzecznie o szacunku, jakim go darzono, ale także o rozbudzonych nadziejach Pythona na rozwój przemysłu fryburskiego, któremu miały utorować drogę prace naukowe prowadzone na uniwersytecie. Zmiana na stanowisku asystenta była jedynie formalnością. Wierusz-Kowalski informował o niej Pythona w liście z 12 listopada 1901 roku, a już 20 listopada, podczas posiedzenia rządu kantonalnego, została ona przegłosowana. Jednocześnie przyznano Modzelewskiemu pensję w wysokości 1200 franków rocznie. ${ }^{21}$

\section{Polskie spółki wysokich technologii w szwajcarskim Fryburgu}

Młody, 25-letni Jan Modzelewski uczestniczył oczywiście w pracach Józefa Wierusza-Kowalskiego i Ignacego Mościckiego. Był też świadkiem pierwszych sukcesów związanych z produkcją kwasu azotowego. Zapewne zdawał sobie sprawę, że bez odpowiedniego kapitału szanse na rozwinięcie produkcji są niewielkie. Po kilku miesiącach przygotowań, 1 sierpnia 1902 roku Wierusz-Kowalski z Mościckim powołali do życia towarzystwo z ograniczoną poręką: Komitet Inicjatywny do Wyrobu Produktów Azotowych. Jego celem było wprowadzenie do produkcji przemysłowej metody uzyskiwania produktów azotowych z powietrza za pomocą wyładowań elektrycznych. Spółka, której kapitał został wyceniony na 100 tysięcy franków, w połowie przypadła Kowalskiemu i Mościckiemu, a reszta została wystawiona na sprzedaż. Modzelewski nie dość, że sam wykupił akcje za 10 tysięcy franków, to jeszcze spowodował, że do spółki włączyli się liczni jego znajomi z Podola. Nadzieje związane z nowym przedsięwzięciem musiały być duże, skoro dwie $\mathrm{z}$ akcji spółki zakupił także sam Georges Python. ${ }^{22}$

20 Archiwum Akt Nowych w Warszawie (dalej cyt. AAN) Akta Towarzystwa Kwasu Azotowego we Fryburgu (dalej cyt. Akta TKAF).

${ }^{21}$ Archives de l'Etat de Fribourg (dalej cyt. AEF) Dossier personnel: de Modzelewski Jean.

22 AAN Akta TKAF. 
Inicjatywa wreszcie mogła nabrać tempa. Na początku 1903 roku w budynku Wydziału Nauk Matematycznych i Przyrodniczych, kiedy wszelkie trudności techniczne zostały pokonane, doprowadzono do produkcji kwasu azotowego metodą Mościckiego w skali laboratoryjnej. Kolejny etap prac zakładał budowę próbnej, stukonnej fabryczki, w której przeprowadzone z powodzeniem doświadczenia miałyby rozstrzygnąć o budowie wytwórni na skalę przemysłową. Ze względu na brak wystarczających funduszy na zbudowanie własnej fabryki zapadła decyzja o rozpoczęciu produkcji w zakładzie już istniejącym. Spośród kilku miejsc, zaproponowanych podczas posiedzenia akcjonariuszy, wybór padł na halę produkcyjną w Vevey, dysponującą odpowiednią mocą do przeprowadzenia pierwszych prób.

Pierwotna metoda Mościckiego umożliwiała produkcję kwasu azotowego z mniejszą wydajnością niż technologia pracującego nad tym samym zagadnieniem Kristiana Birkelanda. Przewaga Norwega nie zniechęciła jednak Mościckiego do kontynuowania prac nad utlenianiem azotu. Po kilku miesiącach doświadczeń ze zmodyfikowanym piecem do spalania Mościckiemu udało się osiągnąć wydajność równą norweskiej, a jednocześnie otrzymać wyższą koncentrację tlenków. Kontrola przeprowadzona przez Kowalskiego i Modzelewskiego potwierdziła, że nowa metoda pozwala uzyskać 61 gramów kwasu przy poborze 1 kilowata mocy w ciągu 1 godziny. Nie zadowalając się tym sukcesem, Mościcki ciągle udoskonalał swoją metodę. Ostatecznie trzeci z kolei piec zapewnił wyniki znacznie lepsze niż te, które osiągał norweski naukowiec. Mościcki, choć nie zwiększył wydajności, doprowadził jednak do dwa i pół raz wyższej koncentracji tlenków niż Birkeland. Miało to wpływ na zmniejszenie kosztów drogiej instalacji absorpcyjnej tlenków, zmieniającej je w kontakcie z wodą w kwas azotowy. ${ }^{23}$

Dla Towarzystwa Kwasu Azotowego rok 1905 okazał się przełomowy. Udało się sprzedać wszystkie patenty kondensatorowe za sumę 125000 franków nowej spółce założonej przez Jana Modzelewskiego. Przybycie do Szwajcarii Williama Crookesa i wydanie przez niego pozytywnej opinii na temat pieca Mościckiego zaowocowało pierwszymi kontaktami z przemysłowcami angielskimi, licznie przybyłymi na pokaz we Fryburgu. Natomiast opublikowane sprawozdanie z prac w niemieckim czasopiśmie Elektrotechnische Zeitschrift, spowodowało zainteresowanie się pracami Mościckiego szwajcarskiej firmy Aluminium Industrie. Była ona gotowa dokonać inwestycji i pomóc Towarzystwu Kwasu Azotowego w rozpoczęciu produkcji na skalę przemysłową.

Tak szybka reakcja mogłaby budzić zdziwienie, gdyby nie fakt, że Aluminium Industrie było jednym $\mathrm{z}$ największych producentów aluminium na skalę światową, $\mathrm{z}$ filiami rozsianymi po całym świecie. De facto przedsiębiorstwem zarządzali Niemcy, a w jego władzach ostatnie słowo miały kręgi wojskowe. Aluminium - pierwiastek bardzo lekki miało już wówczas szerokie zastosowanie w przemyśle wojskowym. Jeśli dodamy, że saletra jest jednym ze składników stosowanych do wyrobu materiałów wybuchowych, łatwo się domyślić, że celem władz Aluminium Industrie było stopniowe tworzenie koncernu zbrojeniowego.

${ }^{23}$ Mościcki 1993, ss. 87-88. 
Pomimo pewnych zastrzeżeń, ale i przy zachowaniu wszelkich możliwych środków ostrożności, zawarcie umowy na produkcję kwasu azotowego stanowiło dla fryburskiej spółki okazję, której nie można było zaprzepaścić. Kontrakt podpisano 12 sierpnia 1908 roku. Zgodnie z nim, Aluminium Industrie zobowiązywało się przelać na konto Towarzystwa Kwasu Azotowego sumę 250000 franków, a dochody z patentów miały być dzielone po połowie. ${ }^{24}$

Ten ogromny zastrzyk gotówki pozwolił spółce spłacić wszelkie długi, które w ciągu kilku lat działalności urosły do wysokości 60000 franków, wypłacić sowitą dywidendę wszystkim akcjonariuszom, a dyrekcji - wysokie premie. Na umowie skorzystał także Wydział Nauk Matematycznych i Przyrodniczych. Za wieloletnie i nieodpłatne użytkowanie instrumentów i laboratoriów towarzystwo ofiarowało mu sumę 5000 franków.

Rozpoczęła się budowa pierwszej fabryki kwasu azotowego na skalę przemysłową. Ignacy Mościcki został jej dyrektorem z pensją w wysokości 2000 franków miesięcznie. We wstępnej fazie prace projektowe były prowadzone jeszcze we Fryburgu, ale fabryka powstała w Chippis, w kantonie Wallis (Valais), gdzie Aluminium Industrie posiadało wiele budynków. Przewidywano, że moc fabryki osiągnie 70000 KM. Równocześnie z budową nowej fabryki Mościcki stale ulepszał swoją metodę. Jego uwagę zaprzątał jeszcze problem koncentracji kwasu, który po opuszczeniu maszyn absorpcyjnych był rozcieńczony do 40-50\%. Po rozwiązaniu i tej trudności pierwsza na świecie cysterna ze stężonym kwasem azotowym, otrzymanym z powietrza, wody i przy użyciu energii elektrycznej, opuściła fabrykę w Chippis w 1910 roku. $^{25}$

Jak nowatorska była to metoda, świadczy historia opisana przez Mościckiego w jego pamiętnikach. Podczas Wielkiej Wojny państwa centralne, produkujące kwas azotowy starą metodą, próbowały zwerbować do współpracy jednego z technologów fabryki w Chippis, wykształconego przez Mościckiego, i w ten sposób uzyskać informacje dotyczące jego metody uzyskiwania kwasu. Cały proces był jednak zbyt skomplikowany i próby te zakończyły się fiaskiem. ${ }^{26}$

Wyprodukowanie tego związku chemicznego było głównym celem Towarzystwa Kwasu Azotowego, jaki został sformułowany jeszcze w 1902 roku. Jego osiągnięcie spowodowało, że działalność spółki znacznie osłabła. Prowadzono jeszcze prace nad kwasem cyjanowodorowym, które także doprowadzono do szczęśliwego końca, ale Mościcki już mniej się w nie angażował.

Prowadził już w tym czasie rozmowy na temat objęcia stanowiska profesora Politechniki we Lwowie, do którego wyjechał w 1912 roku. Jak się miało okazać, swe bogate doświadczenia ze współpracy z Józefem Wieruszem-Kowalskim i jego wizję kształcenia studentów Ignacy Mościcki z powodzeniem zastosował w nowej placówce. On także doszedł do przekonania, że przy stale wzrastających potrzebach przemysłu, kształcenie przyszłych naukowców i inżynierów jedynie na poziomie teoretycznym i laboratoryjnym jest

\footnotetext{
24 AAN Akta TKAF.

25 Brzozowski, Jędruszczak 1977, s. 144.

${ }_{26}$ Mościcki 1993, ss. 96-97.
} 
niewystarczające. Utrzymywał rozlegle kontakty ze środowiskiem przemysłowców i do tego samego namawiał swoich studentów. ${ }^{27}$

Pracy jedynie w spółce nie mógł poświęcić się również Wierusz-Kowalski. Jego podstawową działalnością była ciągle praca w uniwersytecie. Ostatecznie i on powrócił do Polski, do Warszawy, gdzie w 1915 roku rozpoczął jednocześnie wykłady na Uniwersytecie i na Politechnice Warszawskiej. We Fryburgu ostał się jedynie Modzelewski, który pozostał akcjonariuszem Towarzystwa Kwasu Azotowego do jego rozwiązania w 1929 roku.

Polski wkład we fryburską rewolucję przemysłową nie zakończył się na wdrożeniu do produkcji metody otrzymywania kwasu azotowego, opracowanej przez Mościckiego. Miał jeszcze drugą odsłonę, tym razem za sprawą sprytu i możliwości finansowych najmłodszego z trójki polskich naukowców - Jana Modzelewskiego.

Opisana wyżej metoda wymagała zastosowania kondensatorów na wysokie napięcie, które Mościckiemu szczęśliwie udało się skonstruować. Członkowie Towarzystwa Kwasu Azotowego i ten wynalazek postanowili wdrożyć do produkcji. W lecie 1903 roku, kiedy nie wiedziano jeszcze jak będzie odbywać się pozyskiwanie azotu z powietrza, podczas jednego z posiedzeń zarządu Wierusz-Kowalski zaproponował utworzenie nowej spółki, która zajmowałaby się wyłącznie produkcją kondensatorów. Zyski z ich sprzedaży, a także ze sprzedaży akcji spółki, miałyby pokrywać ciągle rosnące wydatki związane z badaniami nad produkcją kwasu azotowego.

Z niebanalną propozycją wystąpił 28-letni wówczas Jan Modzelewski. Zobowiązał się on do wykupu patentów kondensatorowych i sfinansowania produkcji kondensatorów $\mathrm{z}$ własnych środków. Powodzenie przedsiębiorstwa było zapewnione od pierwszego dnia jego powstania. Oczywistym było, że kondensatory potrzebne będą do produkcji kwasu azotowego. Na dodatek, jeszcze podczas wstępnych negocjacji, miejska spółka wodociągowa zamówiła ponad 200 kondensatorów z zapewnieniem, że jeśli ich jakość pozostanie na wysokim poziomie, to zamówienia będą kontynuowane. ${ }^{28}$

Pierwsza wytwórnia pod nazwą Szwajcarska Fabryka Kondensatorów Jana Modzelewskiego powstała już w grudniu 1903 roku. W styczniu 1904 roku Modzelewski wynegocjował jeszcze wyłączność na produkcję kondensatorów Mościckiego na terenie Szwajcarii, w zamian za zapis, że żaden z jego kondensatorów nie zostanie sprzedany innemu przedsiębiorstwu produkującemu kwas azotowy. Te punkty kontraktu zapewniały Modzelewskiemu pozycje monopolisty, co przyczyniło się do szybkiego rozwoju przedsiębiorstwa. Budynki powstały na terenie sprzedanym przez miejską spółkę wodociągową i wkrótce firma zatrudniała około 30 osób.

Zapewnienie sobie zamówień i zbytu całej produkcji pozwoliły Modzelewskiemu poszerzyć działalność. 24 listopada 1905 roku powołał on Towarzystwo Generalne Kondensatorów Elektrycznych - kolejną spółkę, której celem była produkcja i sprzedaż kondensatorów, a także wszelkich elementów niezbędnych do ich działania. Kapitał zakładowy został wyceniony na 300000 franków, ale mógł zostać podniesiony do wysokości

\footnotetext{
27 Lichocka 2014, s. 145.

28 AAN Akta TKAF.
} 
370000 franków, jeśli tak zadecydowałoby walne zgromadzenie akcjonariuszy. Kapitał został podzielony na 600 akcji, każda o wartości 500 franków.

Modzelewski pozostał naczelną postacią w spółce. To on wnosił aport w postaci firmy, która kondensatory już produkowała. Był w trakcie negocjacji z miastem Fryburg w sprawie zakupu 27-arowej parceli pod nową i jeszcze większą fabrykę. Posiadał także prawa do sprzedaży kondensatorów na terenie Szwajcarii Węgier, Niemiec, Anglii, Francji, Austrii, Rosji i Norwegii. Prawa te, jak i pakiet 14 patentów kondensatorowych, były wynikiem dwóch umów - jednej, zawartej z Towarzystwem Kwasów Azotowych i drugiej, z samym Ignacym Mościckim - podpisanych w listopadzie 1905 roku. Wartość tych wkładów oscylowała wokół sumy 90000 franków, co powodowało, że Modzelewski został właścicielem 152 akcji. Otrzymał on także, jako założyciel spółki, 20 akcji beznominałowych, które dawały prawa do uzyskiwania dywidendy. Natomiast Mościcki, bez którego nie doszłoby do rozpoczęcia produkcji, otrzymał raptem 25 akcji nowej spółki. ${ }^{29}$

Operacja o charakterze czysto finansowym, jaką w rzeczywistości przeprowadził Modzelewski i skład zarządu spółki, dobrze pokazują, jak z niewielkiej firmy o produkcji wielkości raczej laboratoryjnej doszło do stworzenia instytucji finansowej na dużą skalę. Jej członkami zostali: Georges Bougère, francuski bankowiec z Angers, inżynier Georges Gilles, Francuz pochodzenia amerykańskiego, wnuk konsula Stanów Zjednoczonych w Paryżu, Fritz Graenicher, dyrektor Powszechnego Banku Szwajcarskiego, Rodolphe de Weck, dyrektor Towarzystwa Tramwajów, Karol Sulikowski, syn dyrektora Kolei Warszawsko-Wiedeńskiej, przedsiębiorcy i zamożnego ziemianina, oraz Modzelewski jako założyciel spółki.

Po pierwszym okresie sukcesów przedsiębiorstwa liczba zamówień na kondensatory wysokiego napięcia zaczęła stopniowo maleć. Z czasem główny odbiorca fryburskich kondensatorów, którym był przemysł telegraficzny, wynalazł nowe technologie i zaprzestał stosowania tych urządzeń. Mimo iż największa stacja telegraficzna, znajdująca się na wieży Eiffla, nadal się nimi posługiwała, przyszłość Towarzystwa Kondensatorów stanęła pod znakiem zapytania.

W sukurs Modzelewskiemu także i tym razem przyszedł Mościcki. Specjalnie dla spółki opracował metodę zabezpieczania sieci przewodów elektrycznych od przepięć wywołanych zaburzeniami atmosferycznymi. Nowy produkt także i tym razem spotkał się z ogromnym zainteresowaniem podczas zorganizowanego we Fryburgu Kongresu Elektryków. Zamówień przybywało, a obroty w pierwszym roku od wprowadzenia nowego produktu wzrosły o milion franków. ${ }^{30}$ Fabryka, sumiennie prowadzona na co dzień przez Gilles’a, zatrudniała już wówczas około 50 osób. Kiedy Polacy skupili całość swoich zainteresowań na innych zagadnieniach, Georges Gilles został jej dyrektorem i również przyczynił się do poszerzenia gamy produktów spółki. Sam skonstruował między innymi oscylatory, zawory, bezpieczniki, ograniczniki przepięć i odłączniki. Zapewne dzięki jego zaangażowaniu dobra passa firmy trwała jeszcze w okresie pierwszej wojny światowej. Po

\footnotetext{
29 AEF Statut Generalnego Towarzystwa Kondensatorów Elektrycznych we Fryburgu.
}

${ }^{30}$ Mościcki 1993, s. 94. 
jej zakończeniu Towarzystwo Kondensatorów poczęło tracić impet, a już całkowicie podupadło po nieoczekiwanej śmierci Gilles’a w 1920 roku.

\section{Epilog}

Burzliwy okres wojenny spowodował, że trzej Polacy opuścili stery stworzonych przez siebie spółek. Jak wspomniano już wcześniej, Ignacy Mościcki udał się do Lwowa, natomiast kilkanaście lat później został prezydentem Rzeczpospolitej Polskiej. Józef Wierusz-Kowalski po zakończeniu wojny prowadził jeszcze wykłady w Warszawie, ale w niedługim czasie wybrał karierę dyplomatyczną i udał się na placówkę do Watykanu. Jan Modzelewski, który pozostał w Szwajcarii, w czasie wojny zajął się pomocą humanitarną. Działał w polskich organizacjach niepodległościowych, by ostatecznie zostać Posłem Nadzwyczajnym i Ministrem Pełnomocnym Rzeczypospolitej Polskiej w Bernie.

Troska o losy Polski i Polaków, i rozbudzone nadzieje na odzyskanie niepodległości spowodowały społeczne i polityczne zaangażowanie naukowców, sprawiając tym samym, że ich zdolności naukowe nie zostały bardziej wykorzystane, a praca badawcza musiała zejść na dalszy plan. Jednak ich osiągnięcia w czasie 30-40 lat pobytu w Szwajcarii pokazują, że ogromny potencjał, odpowiednio wcześnie odkryty i dobrze ukierunkowany, nawet w najmniej sprzyjających warunkach może przynieść nadspodziewane efekty. By jednak postęp w nauce, a co za tym idzie w życiu państw i społeczeństw, mógł się dokonywać, niezbędna jest całościowa i spójna wizja politycznych decydentów, rozumiejących jego znaczenie i gotowych wspierać rozwój wiedzy, niezależnie od kosztów z tym związanych. Dzięki tej unii świata polityki, nauki i finansów ubogi i rolniczy kanton fryburski przeprowadził szereg śmiałych reform, w których kluczową rolę odegrali Polacy.

\section{BIBLIOGRAFIA}

\section{ZBIORY ARCHIWALNE}

Archiwum Akt Nowych w Warszawie

Akta Towarzystwa Kwasu Azotowego we Fryburgu.

Archives de l'Etat de Fribourg

Dossier personel: de Modzelewski Jan.

Statut de la société anonyme Société Générale des Condensateurs Electriques à Fribourg (Suisse).

\section{OPRACOWANIA}

\section{ALTERMATT Urs}

1991: Die Gründung. [In:] Histoire de l'Université de Fribourg Suisse 1889-1989, Vol. 1. Roland Ruffieux (dir.). Fribourg: Editions Universitaires Fribourg Suisse. ISBN 2-8271-0561-6, ss. 32-74. 
BRZOZOWSKI Stanisław M., JĘDRUSZCZAK Tadeusz

1977: Ignacy Mościcki. [W:] Polski Słownik Biograficzny, t. XXII. Pod redakcją Emanuela Rostworowskiego. Wrocław, Warszawa, Kraków, Gdańsk: Zakład Narodowy im. Ossolińskich. ss. 143-148.

BUGNARD Pierre

1981: Le régime Python. [W:] Histoire du Canton de Fribourg. Vol. 2. Pod redakcją Rolanda Ruffieux. Fribourg: Editions St. Paul, ss. 875-887.

GIOVANNINI Edgardo

1991: La Faculté des Sciences. [In:] Histoire de l'Université de Fribourg Suisse 1889-1989, Vol. 2. Roland Ruffieux (dir.). Fribourg: Editions Universitaires Fribourg Suisse. ISBN 2-8271-0561-6, ss. 776-798.

JORDAN Joseph

1943: Banque de l'Etat de Fribourg. Cinquante ans d'activité 1892-1942. Fribourg: Imprimerie Saint-Paul.

KASPEROWICZ Konrad

1904: Studien über die Festigkeit von Dielektrika. Freiburg: St.-Paulus Druckerei.

LICHOCKA Halina

2011: Ignacy Mościcki. Radom: Wydawnictwo Naukowe Instytutu Technologii Eksploatacji PIB. ISBN 978-83-7204-981-0.

2014: Swiss experiences of Ignacy Moscicki. Technical Transactions 1, pp. 137-149. Available online: https://suw.biblos.pk.edu.pl/resources/i5/i4/i6/i1/i8/r54618/LichockaH SwissExperiences.pdf (15.11.2015).

MODZELEWSKI Jan

1908: Etude sur l’emploi, comme condensateur, d'éléments électrolytiques à électrodes d'aluminium. Fribourg: Imprimerie Fragnière Frères.

MOŚCICKI Ignacy

1993: Autobiografia. Warszawa: Bellona. ISBN 83-1108-265-0.

PHILIPONA P.

1924/1925: Le jubilé de M. Georges Python. Cinquante ans d'histoire. Monat-Rosen 69, p. 37. RUFFIEUX Roland

(red.) 1991-1992: Histoire de l'Université de Fribourg Suisse 1889-1989. Vol. 1-3. Fribourg: Editions Universitaires Fribourg Suisse. ISBN 2-8271-0561-6.

ŚREDNIAWA Bronislaw, ZABIEŁŁO Stanisław

1968-1969: Józef Wierusz-Kowalski. [W:] Polski Słownik Biograficzny, t. XIV. Pod redakcją Emanuela Rostworowskiego. Wrocław, Warszawa, Kraków: Zakład Narodowy im. Ossolińskich, ss. 558-560. 
WALTER François

1981: Fribourg à l'écart de la révolution industrielle (1847-1881). [In:] Histoire du Canton de Fribourg. Vol. 2. Roland Ruffieux (dir.). Fribourg: Editions St. Paul, pp. 897-905.

1973/1974: Fribourg et l'industrie au XIXème siècle: Léchec de la Société des Eaux et des Forets (1869-1875). Annales Fribourgeoises 52, p. 73-137.

WYBRANOWSKI Roman

1904: Etude sur la charge des condensateurs. Fribourg: Imprimerie Saint Paul.

ZDANOWSKI Bruno

1904: Nouvelle méthode pour la mesure des résistances liquides. Fribourg: Imprimerie Saint Paul.

\author{
POLISH ORIGINS OF THE FACULTY \\ OF MATHEMATICAL AND NATURAL SCIENCES \\ OF THE UNIVERSITY OF FRIBOURG \\ AND THE POLISH CONTRIBUTION \\ TO THE FRIBOURG INDUSTRIAL REVOLUTION
}

\begin{abstract}
The article is dedicated to high-tech companies founded by Poles at the end of the 19th century in the rural canton of Fribourg in Switzerland. The text is divided into two parts. In the first part, the author attempts to present the economic, social and political reality of Fribourg in a period of intense industrialization in the world and the formation of the liberal free market system. In this rapidly changing reality, the new Catholic-conservative authorities of the canton tried to lead to establishing of a comprehensive, but also different system of a "Christian republic", whose aim was to achieve social justice consistent with the teachings of the Gospel. In order to complete the project, the cantonal government did not shy away from using the possibilities and measures offered by the contemporary world. Decision-makers, led by Georges Python, needed support from the society, who was aware of the changes. Due to this fact, it became necessary to establish a university capable of shaping new attitudes and views. However, the costs significantly exceeded the financial capabilities of the agricultural and relatively poor canton of Fribourg. In these less favourable circumstances, a conscious policy of industrialization was the way out of the deadlock. Newly created industrial institutions were to contribute to an increase of cash inflows to the canton and thus allow for the financing of the university, which would also become an intellectual foundation for the emerging industry. The activity of Polish
\end{abstract}


scientists, which is the subject of the second part of the article, matched this philosophy perfectly. The Poles invited to cooperate with Python, i.e. Józef Wierusz-Kowalski, Ignacy Mościcki and Jan Modzelewski, created the foundations of the Faculty of Mathematical and Natural Sciences at the University of Fribourg. As members of the faculty, in addition to teaching, they conducted research into, among other things, nitric acid synthesis and construction of electrical capacitors. Convinced of the need to put their innovations into wide production, they financed and built the first experimental factories and, over time, led to the development of a nitric acid factory and a high-voltage capacitor factory on an industrial scale. Although after the First World War the commitment of the Poles stopped, the 30 years of academic research and experience clearly showed that a conscious cooperation of policy-makers and highly qualified scientific personnel can bring surprising and unexpected results.

Keywords: University of Fribourg, Faculty of Mathematical and Natural Sciences, industrialization, applied science, industry, nitric acid, capacitors, electric discharge, nitre, synthesis of nitrogen and oxygen, "Christian republic", Catholic social teaching, joint stock company, factory, patents, Society of Nitric Acid, Swiss factory of capacitors, General Society of Electric Capacitors 